\title{
Serological study of hantavirus in man in the Autonomous Community of Madrid, Spain
}

\author{
L. LLEDÓ , M. I. GEGÚNDEZ, J. V. SAZ, M. J. ALVES* and M. BELTRÁN
}

Department of Microbiology and Parasitology, Faculty of Medicine, Alcala University, Spain and *Centro de Estudos de Vectores e Doenças Infecciosas. Aguas de Moura, Portugal

\begin{abstract}
Data relating to hantavirus infection in Spain are scarce and limited to rural areas. The aim of this work was to study the seroprevalence of hantavirus infection in the Autonomous Community of Madrid (ACM), a region containing both rural and urban populations in different ecological settings. Sera from 3852 individuals (1849 male, 2003 female) were screened by indirect inmunofluorescence, with Vero E6 cells infected with Puumala, Hantaan and Seoul viruses as antigens. Screen-positive results were confirmed by Western blot with recombinant Seoul virus nucleocapsid protein as antigen. Antibodies against hantavirus were detected in 12 sera $(0.31 \%)$. No statistical differences were found according to sex and age. The highest prevalence was found in the southeastern area, significantly higher than the central and north-western areas. The most frequent serological pattern was reactivity against all three viruses used $(33.3 \%$ of all positive sera). Therefore, this study confirms the presence of hantavirus infection in the ACM, including for the first time an urban area of Spain, but with the highest prevalence in a rural area. Serological evidence suggests that there is more than one circulating serotype.
\end{abstract}

\section{Introduction}

Infection with hantaviruses, belonging to the family Bunyaviridae, may result in several illnesses with different clinical evolution and prognosis, from asymptomatic infection, through mild illness such as epidemic nephropathy, to life-threatening conditions such as hantavirus pulmonary syndrome. The severity of the disease depends on the particular virus serotype. There are numerous species of hantaviruses that may cause disease in man. Their distribution is world-wide, with particular endemic areas being south-eastern Asia, northern and eastern parts of Europe and, more recently, south-western USA [1].

Rodents are the natural reservoir of hantaviruses, both in the countryside and in cities, although these viruses have been reported in other animals as well [2-4]. The main route of infection in man is via the respiratory

Received 13 Nov. 2001; revised version accepted 7 May 2002.

Corresponding author: Dr L. Lledó (e-mail: lourdes.lledo @uah.es). tract by the inhalation of aerosols originating from rodent urine, excrement and saliva [5].

In Spain, data concerning infection with these viruses are scant, with most recent studies performed only in small geographical areas $[6,7]$. Knowledge of animal reservoirs is also very limited. One study, conducted in three provinces of the Peninsular Central region, reported the presence of seven species of rodents with specific antibodies for hantaviruses (L. Lledó et al., unpublished observations). The clinical significance of hantavirus infection is also unclear, with a very limited number of studies, with only small numbers of appropriate patients with compatible pathology $[8,9]$.

The aim of this study was to examine the seroprevalence of hantavirus infection in Spain in a large population base. The Autonomous Community of Madrid (ACM) was chosen because of its ecological and social features. The ACM is located in the centre of Spain, with an area of $8027.9 \mathrm{~km}^{2}$ and a population of 5172229 inhabitants (National Institute of Statistics, 1 Jan. 1995). It includes a mountain range in the north-west, as well as flat areas with hills criss-crossed by several rivers in the south-east. It has urban municipalities in the centre, bordering vast areas used for agriculture and cattle raising. 


\section{Materials and methods}

\section{Serum specimens}

A total of 3852 serum samples was obtained from the general population of the ACM who entered healthcare centres (for whatever reason), during the period from March to Dec. 1996. Sera were stored at $-20^{\circ} \mathrm{C}$ until further analysis. In all, 1849 samples were from males (48\%) and 2003 from females (52\%). The mean age of the patients was 42 years (range 1-91). For the purposes of analysis, the territory of the ACM was divided into three distinct ecological and social areas (rural or urban population, vegetation, climate) as follows. The north-western area (1536 sera) is characterised by high altitudes, lower temperatures and greater precipitation than in the other areas. In this area, urban and rural municipalities converge, and cattle-raising is an important activity. The central area (1158 sera) is typically urban; and the south-eastern area (1158 sera), with higher temperatures and the lowest annual rainfall, is dotted with numerous rural municipalities dedicated fundamentally to agriculture. The geographical distribution of the samples is shown in Fig. 1.

The samples were obtained according to the ethical standards of the Alcala University committee on human experimentation and in accordance with the Helsinki declaration of 1975, as revised in 1983.

\section{Indirect immunofluorescence assay (IFA)}

Sera were tested by IFA, as described previously by Lee et al. [10]. Puumala (strain Hallnäs-B1), Hantaan (strain 76/118) and Seoul (strain 80/39) viruses were used. Viruses were propagated in Vero E6 cells (ATCC CRL 1586) and fixed on spot slides. The fluoresceinlabelled conjugate used was a rabbit anti-human IgA, IgG and IgM serum (Sigma), diluted 1 in 128 in PBS containing Evan's blue. Sera showing a typical pattern of fluorescence at titres $\geqslant 32$ were considered positive.

\section{Western blots (WB)}

These were performed according to the protocols described by Jenison et al. [11]. A recombinant plasmid containing the Seoul $\mathrm{N}$ gene expressed from $\mathrm{pET}$ $23 \mathrm{~b}$ vector (Novagen, Madison, WI, USA) was provided by B. Hjelle (Department of Pathology, University of New Mexico, USA). The recombinant nucleocapsid protein was expressed with Escherichia coli BL21 (Novagen). Briefly, the viral antigen was applied to SDS-polyacrylamide $4-12 \%$ gels (BioRad, Hercules, CA, USA) and transferred electrophoretically to nitrocellulose membranes. The membranes were allowed to dry and then cut lengthwise into 2-mm-wide strips with a hand-held paper shredder. The strips were stored at $4^{\circ} \mathrm{C}$ in PBS buffer containing non-fat dried milk 5\%. Serum samples were pre-incubated for $6 \mathrm{~h}$ in a Western blot tray (BioRad) with a blocking reagent

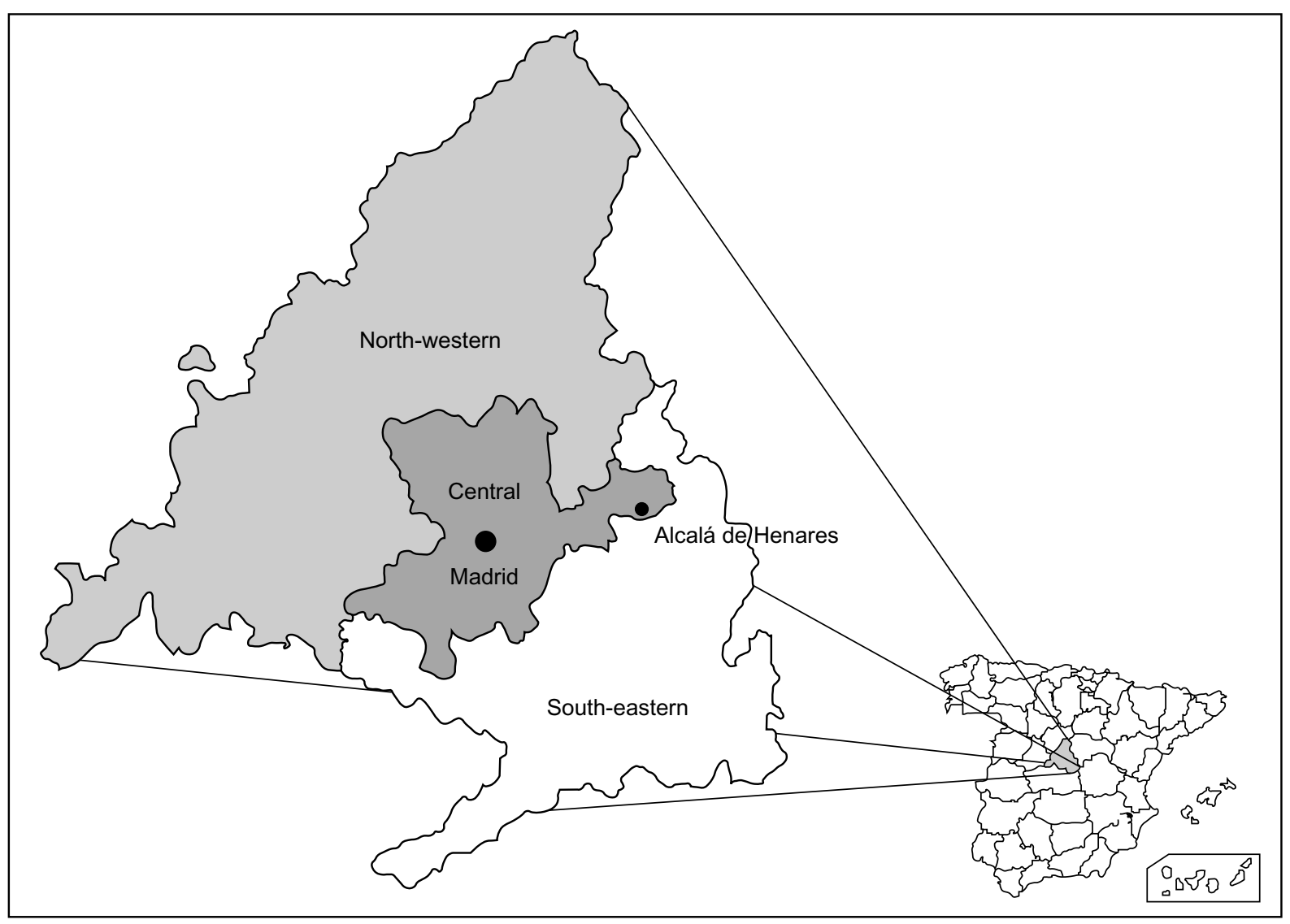

Fig. 1. Geographical distribution of the samples. 
that consisted of a detergent lysate of $E$. coli in PBS buffer containing milk 5\%, at 1 in 400 dilution [11]. The antigen-containing strips were then placed into the wells in the tray and incubated overnight at $4^{\circ} \mathrm{C}$. The strips were rinsed in detergent-PBS buffer $(10 \mathrm{mM}$ sodium phosphate, $\mathrm{pH} 7.4$, deoxycholic acid $0.5 \%$, Triton X-100 0.5\%, 0.1 M NaCl), and incubated with a 1 in 1000 dilution of alkaline phosphatase-conjugated goat anti-human IgG (Sigma) for $4 \mathrm{~h}$ and then rinsed again. Nitroblue tetrazolium and 5-bromo-4-chloro-3indoyl-phosphate substrate (Sigma) were added for $10 \mathrm{~min}$ and finally the strips were rinsed with distilled water.

\section{Statistical analysis}

Differences in proportions in two-way tables were made, by the $\chi^{2}$ or the Fisher's exact test, with Stat View $^{\circledR}$ software in Apple ${ }^{\mathrm{TM}}$ format.

\section{Results}

In all, 52 sera $(1.35 \%)$ with significant antibody titres against hantavirus were detected by IFA; 12 of these $(0.31 \%)$ were confirmed by Western blotting (Fig. 2).

Seven sera were from male $(0.38 \%)$ and five from female $(0.24 \%)$ subjects, age range $16-78$ years with a mean of 50.1 years. The age distribution of seroprevalence is shown in Fig. 3. No statistical differences were found according to sex or age.

Three sera from the north-western area were positive $(0.19 \%)$, eight from the south-eastern area $(0.69 \%)$ and one $(0.08 \%)$ from the central area. The prevalence in the south-eastern area was significantly higher than in the other areas $(\mathrm{p}<0.05)$.

Nine $(0.23 \%)$ sera reacted in IFA with Puumala virus,

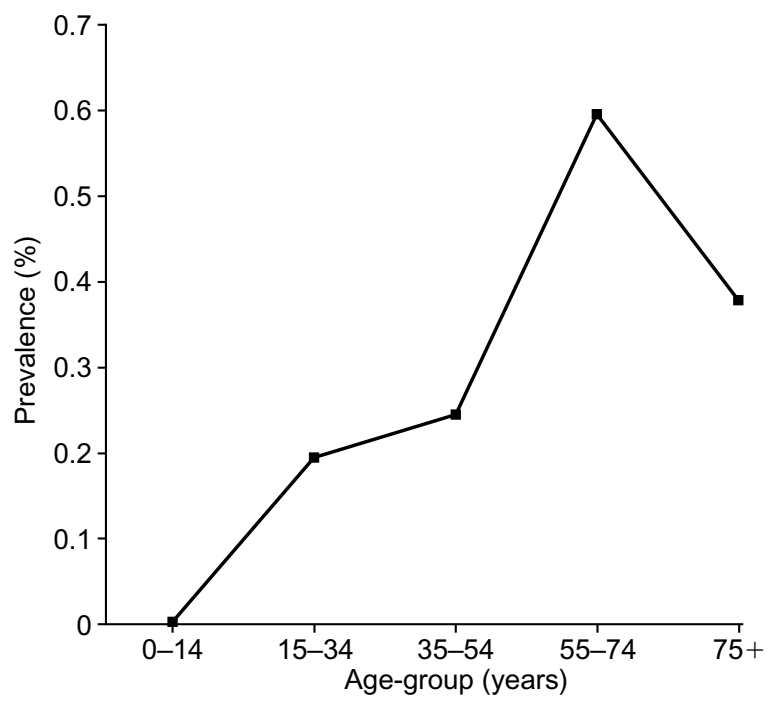

Fig. 3. Hantavirus antibody prevalence by age groups.

nine $(0.23 \%)$ with Seoul virus and seven $(0.18 \%)$ with Hantaan virus. Six serological patterns were distinguished, the most frequent being reactivity to all three viruses $(33.3 \%)$. Titres of the positive sera ranged from 32 to 512 .

\section{Discussion}

This study demonstrated the presence of hantavirus antibodies in the general population of the ACM in Spain. The seroprevalence was lower than that reported in other European countries including Italy $2.3 \%$ [12], the Netherlands $0.9 \%$ [13], Germany $1.7 \%$ [14], Greece 4-14\% [15] and Finland $5 \%$ (range $0-12 \%$ dependent on region) [16]. However, in those studies, only IFA or enzyme immunoassay (EIA) were used to detect antibodies.

In Spain, epidemiological studies have been performed in the mainly rural populations of Soria [6] and

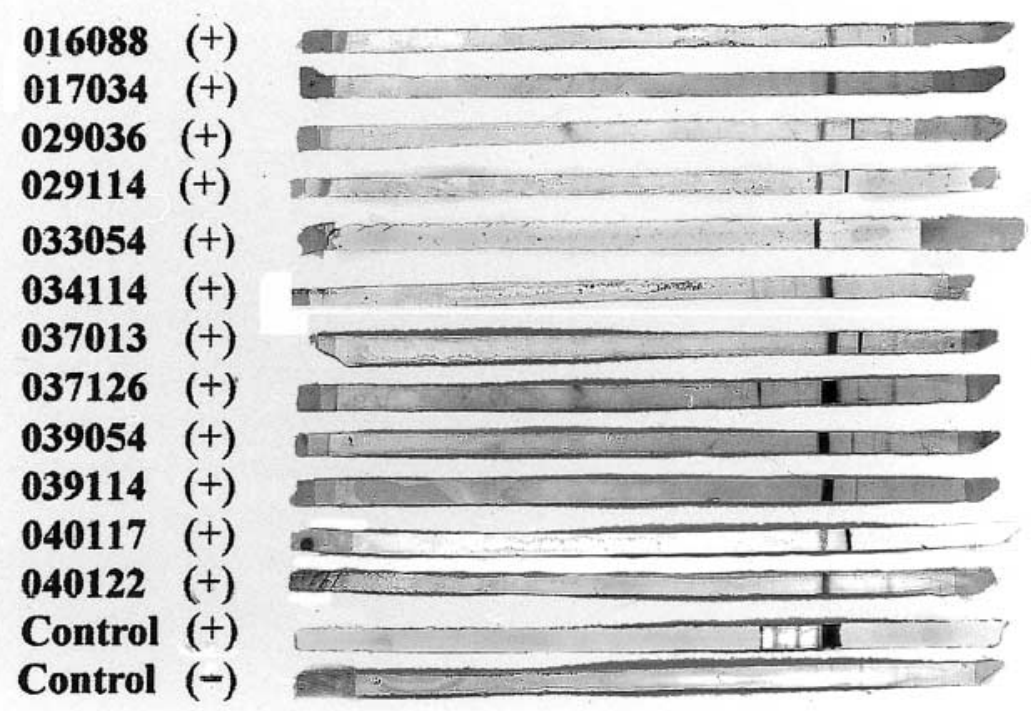

Fig. 2. Positive samples by Western blotting. 
Guadalajara [17] provinces, with seroprevalence rates of $2.2 \%$ and $1.8 \%$, respectively, by IFA. In Cataluña, rates of $0.3-2.3 \%$ were reported $[7,18]$. Therefore, the seroprevalence found in the ACM is very similar to those found in other regions of Spain.

The present study found no significant difference in seroprevalence by sex, similar to a number of other reports, although the male:female ratio of clinical 'epidemic nephropathy' cases may not be $1: 1$, and in Russia was reported as $5: 1[6,17,19,20]$.

The pattern of age-related seroprevalence rates reported here is similar to those from other European studies, e.g., Sweden [19], with the highest prevalence at age 55-74 years. Antibodies against hantavirus remain detectable for decades after infection $[16,21]$ and, therefore, a progressive increase in seroprevalence is to be expected. A seroprevalence of $30 \%$ has been found in elderly subjects in Finland [22].

The highest seroprevalence in this study was in the south-eastern area. This region is dotted with numerous rural municipalities dedicated principally to agriculture; in comparison, the central area is typically urban, and the north-western area combines both urban and rural municipalities, with cattle-raising being an important activity. In general, hantavirus infection affects rural populations more than urban ones [1].

Six serological patterns of reactivity were identified by IFA. The most frequent pattern in the central and north-western areas was reactivity against all three viruses used. In comparison, studies in Italy and Germany suggest that seroreactivity is commonest against Puumala virus [12,14]. Clethrionomys glareolus, the natural reservoir for this virus in Europe, is not present in the ACM, which may explain the decreased importance of Puumala-like virus in this area. Also, the present study was unable to confirm seroreactivity against Puumala virus by Western blot, which may have led to an underestimate of seroreactivity against viruses antigenically related to Puumala. The nucleocapsid protein of Seoul virus may not provide a good substrate for detection of cross-reactivity with Puumala virus [23].

The wild rats Rattus rattus and $R$. norvergicus are the natural reservoir for Seoul virus. These have a worldwide distribution, including Europe, and are also present in the ACM [24], suggesting that the seroreactivity detected against this virus in the present study and a study in Soria [6] may be real. Antibodies specific to Seoul virus were detected by IFA among sera from the general population, patients with acute renal failure and in rodents, in a serological study from Ireland [25]. Seoul antigen was detected in rodent lungs from Portugal [26].

In summary, this study confirms the presence of infection by hantavirus in the ACM. It appears that there is more than one circulating serotype; however, further study, by plaque reduction neutralisation tests, will be necessary to define these precisely. The sensitivity of serological tests may also be improved by use of local strains, when they become available. A better understanding of these infections, including investigation of natural viral reservoirs and of clinical manifestations of infection, is an important goal in Spain.

We thank Dr B. Hjelle for his contribution to the Western blotting assays.

\section{References}

1. Hjelle B, Jenison SA, Goade DE, Green WB, Feddersen RM, Scott AA. Hantaviruses: clinical, microbiologic and epidemiologic aspects. Crit Rev Clin Lab Sci 1995; 32: 469-508.

2. Nowotny N. The domestic cat: a possible transmitter of viruses from rodents to man. Lancet 1994; 343: 921.

3. Kim GR, Lee YT, Park CH. A new natural reservoir of hantavirus: isolation of hantaviruses from lung tissues of bats. Arch Virol 1994; 134: 85-95.

4. Slonova RA, Tkachenko EA, Kushnarev EL, Dzagurova TK, Astakova TI. Hantavirus isolation from birds. Acta Virol 1992; 36: 493 .

5. Schlmaljohn CS, Dalrymple JM. Hantaviruses. In: Webster RG, Granoff A (eds) Encyclopedia of virology, vol 2. London, Academic Press. 1994: 538-545.

6. Gegúndez MI, Saz JV, Alves MJ, Merino FJ, Filipe AR, Beltrán M. Infección por Hantavirus en España: Estudio seroepidemiológico en la provincia de Soria. [Hantavirus infection in Spain: seroepidemiologic study in the province of Soria.] Med Clin 1996; 106: 131-133.

7. Rodríguez JA, Vaqué J. La enfermedad por Hantavirus: una infección emergente. [Hantavirus disease: an emerging infection.] Enferm Infecc Microbiol Clin 1994; 12: 477-479.

8. Salavert M, López-Hontangas JL, Ponz F, Gobernado M. Infección por Hantavirus y síndrome pulmonar, otra nueva entidad que buscar en nuestro entorno? [Hantavirus infection and the pulmonary syndrome: another new entity to look for in our environment?] Enferm Infecc Microbiol Clin 1996; 14: 395-396.

9. Pérez-Molina JA, Escudero Nieto R, Settergren B, Guerrero Espejo A. Debemos buscar la infección por Hantavirus en pacientes españoles? [Should we look for Hantavirus infection in Spanish patients?] Enferm Infecc Microbiol Clin 1995; 13: $125-126$.

10. Lee HW, Lee PW. Korean hemorrhagic fever I. Demonstration of causative antigen and antibodies. Korean $J$ Intern Med 1976; 19: 371-383.

11. Jenison S, Yamada $\mathrm{T}$, Morris $\mathrm{C}$ et al. Characterization of human antibody responses to Four Corners Hantavirus infection among patients with Hantavirus pulmonary syndrome. $J$ Virol 1994; 68: 3000-3006.

12. Nuti M, Amaddeo D, Autorino GL et al. Seroprevalence of antibodies to hantaviruses and leptospires in selected Italian population groups. Eur J Epidemiol 1992; 8: 98-102.

13. Groen J, Gerding MN, Jordans JG, Clement JP, Nieuwenhuijs JHM, Osterhaus ADME. Hantavirus infections in The Netherlands: epidemiology and disease. Epidemiol Infect 1995; 114: 373-383.

14. Zollër L, Faulde M, Meisel H et al. Seroprevalence of hantavirus antibodies in Germany as determined by a new recombinant enzyme immunoassay. Eur J Clin Microbiol Infect Dis 1995; 14: 305-313.

15. Papadimitriou MG, Antoniadis A. Hantavirus nephropathy in Greece. Lancet 1994; 343: 1038.

16. Brummer-Kurvenkontio M, Vapalahti O, Henttonen H, Koskela P, Kuusisto P, Vaheri A. Epidemiological study of Nephropathia epidemica in Finland 1989-96. Scand J Infect Dis 1999; 31: 427-435.

17. Saz JV, Gegúndez MI, Beltrán M. Hantavirus. Zamora, Junta 
de Castilla y León, Consejeria de Sanidad y Bienestar Social. 1997

18. Mustonen J, Vaheri A, Clement J. Third International Conference on Haemorrhagic Fever with Renal Syndrome (HFRS) and Hantaviruses. Nephrol Dial Transplant 1996; 11: 730-733.

19. Ahlm C, Linderholm M, Juto P, Stegmayr B, Settergren B. Prevalence of serum IgG antibodies to Puumala virus (haemorrhagic fever with renal syndrome) in Northern Sweden. Epidemiol Infect 1994; 113: 129-136.

20. Niklasson B, Hornfeldt B, Mullaart M et al. An epidemiologic study of hemorrhagic fever with renal syndrome in Bashkirtostan (Russian) and Sweden. Am J Trop Hyg 1993; 48: $670-675$.

21. Settergren B, Ahlm C, Juto P, Niklasson B. Specific Puumala virus IgG half a century after haemorrhagic fever with renal syndrome. Lancet 1991; 338: 66.
22. Vapalahti O, Kallio-Kokko H, Närvänen A et al. Human B-cell epitopes of Puumala virus nucleocapsid protein, the major antigen in early serological response. J Med Virol 1995; 46 : 293-303.

23. Salonen E-M, Parren PWHI, Graus YF et al. Human recombinant Puumala virus antibodies: cross-reaction with other hantaviruses and use in diagnostics. J Gen Virol 1998; 79: $659-665$.

24. Castell A, Mayo M. Guía de los mamíferos en libertad en España y Portugal. Madrid, Editorial Pirámide. 1993: 157-160.

25. McKenna P, Clement J, Matthys P, Coyle PV, McCaughey C. Serological evidence of hantavirus disease in Northern Ireland. J Med Virol 1994; 43: 33-38.

26. Filipe AR, Andrade HR, Sommer AI, Traavik T. Hantaviral antigens and antibodies in wild rodents in Portugal. Acta Virol 1991; 35: 287-291. 